\title{
Terapia ręki - od teorii do prakłyki. Założenia pedagogiczne Marii Montessori w świetle współczesnej teorii
}

\section{Hand Therapy - from Theory to Practice. Maria Montessori's Pedagogical Assumptions in the Light of Modern Theories}

\section{SŁOWA KLUCZE ABSTRAKT}

terapia ręki, metoda

Montessori, ćwiczenia praktycznego życia, przygotowane otoczenie, rozwój dziecka, rozwój motoryczny, mała motoryka, chwyt pisarski
Celem niniejszego artykułu jest przedstawienie założeń teoretycznych na temat terapii ręki oraz wskazanie możliwości terapeutycznych związanych z rozwojem dużej i małej motoryki w pracy dzieci z materiałem rozwojowym Marii Montessori. Współczesne teorie związane z wielowymiarową stymulacją motoryczną dziecka mają swoje przełożenie na koncepcję pedagogiczną Marii Montessori, która umożliwia doskonalenie poszczególnych umiejętności dzieci przez cały czas przebywania w placówce. Środkiem osiągnięcia zamierzonych celów terapeutycznych w koncepcji Montessori jest odpowiednio przygotowane otoczenie, dające szansę wielokrotnego powtarzania danej czynności oraz poprawę jakości jej wykonania. W części pierwszej artykułu przedstawiono najważniejsze etapy rozwoju motorycznego dziecka i wskazano oddziaływania prawidłowego kształtowania się motoryki dużej i małej na funkcjonowanie dłoni dziecka. Następnie opisano główne założenia terapii ręki, by przejść do przedstawienia praktycznych rozwiązań w metodzie Montessori. Na podstawie analizy pro- 
pozycji materiałów rozwojowych w obszarach: ćwiczeń praktycznego życia, rozwijających zmysły i mowę, wskazano przykłady aktywności, które wspierają i przygotowują dziecko do szkoły.

\section{KEYWORDS ABSTRACT}

hand therapy, The aim of the article is to present theoretical assumptions of hand Montessori method, practical life therapy and to indicate therapeutic possibilities of Maria Montessori's developmental material related to the improvement of gross and fine exercises, prepared motor skills. Modern theories related to the child's multidimensional environment, child motor stimulation can be reflected in Maria Montessori's pedagogidevelopment, cal concept which enables the improvement of children's individual physical development, fine skills by repeating many basic activities throughout the day thanks to prepared environment. The first part of the article presents the motor skills, pencil most important stages of a child's motor development and indicates grasp its influence on the functioning of a child's hand. Then, the author describes the main assumptions of hand therapy and presents some practical solutions in the Montessori method. Based on the analysis of the suggested development materials in the areas of practical life exercises that develop senses and speech, examples of activities that support and prepare the child for school are indicated.

\section{Wprowadzenie}

Współczesna rzeczywistość przedszkolna oraz szkolna pokazuje, że wiele dzieci zmaga się z problemami związanymi z rozwojem motorycznym. Mimo osiągania poszczególnych kamieni milowych rozwoju ruchowego, coraz więcej dzieci ma trudności z uzyskaniem dojrzałości motorycznej, która przejawia się obniżoną sprawnością kończyny górnej, co wpływa na jakość wykonywania wielu czynności tj. chwytanie, pchanie, siłowanie, podnoszenie, manipulowanie przedmiotami, wykonywanie precyzyjnych ruchów rąk, dłoni i palców. Obniżona sprawność małej motoryki wpływa na wiele aspektów życia dziecka, m.in. zakłóca zdobywanie umiejętności samoobsługowych oraz czynności manipulacyjnych np. wycinanie, klejenie, utrudnia osiągnięcie dojrzałego chwytu pisarskiego. Można zatem stwierdzić, że sprawność ręki i jej wyspecjalizowanie decyduje o poziomie funkcjonowania dziecka.

Naprzeciw dzieciom z wyżej wymienionymi trudnościami stają specjaliści wielu dziedzin, aby wspomóc rozwój motoryczny oraz wyrównywać dysharmonie powstałe w procesie rozwoju dziecka, odnosząc się do wiedzy oraz doświadczeń naukowców z zakresu integracji sensorycznej, fizjoterapii, medycy, psychologii rozwojowej, pedagogiki specjalnej itp. W ostatnich latach, w środowisku nauczycieli przedszkolnych i wczesnoszkolnych coraz więcej uwagi poświęca się holistycznemu 
stymulowaniu rozwoju dziecka. Obserwacje pedagogiczne prowadzone są w oparciu o wiedzę zakresu psychologii rozwojowej dotyczącej rozwoju poznawczego, który rozpoczyna się wraz z narodzinami dziecka i w pierwszych latach życia skorelowany jest z rozwojem motorycznym. W związku z tym nauczyciele coraz częściej zwracają uwagę na właściwe wzorce ruchowe, odpowiednią postawę ciała dziecka podczas wykonywania codziennych czynności. Nierzadko opracowują programy pracy z dziećmi uwzględniające stymulację motoryczną, w celu maksymalizowania możliwości oraz wyrównywania braków. Warto jednak zdać sobie sprawę, że umożliwianie dzieciom ćwiczenia podstawowych czynności samoobsługowych oraz wspieranie ich w uczeniu się prostych czynności jest doskonałą stymulacją motoryczną, która prowadzi do sprawności ruchowej oraz buduje w nich poczucie własnej wartości. Takie podejście pracy z dziećmi prezentuje pedagogika Marii Montessori, a jej hasło przewodnie „pomóż mi to zrobić samodzielnie" wskazuje potrzebę indywidualnego działania dziecka pod opieką osoby dorosłej.

Celem niniejszego artykułu jest ukazanie możliwości terapeutycznych pracy z rozwojowym materiałem Montessori w kontekście teorii terapii ręki oraz stymulacji motorycznej dzieci.

\section{Znaczenie rozwoju ruchowego w prawidłowym funkcjonowaniu dłoni dziecka}

Prawidłowy rozwój ruchowy wpływa na wiele obszarów życia dziecka. Determinuje nie tylko rozwój fizyczny, ale również psychiczny oraz społeczny. Badania naukowe dowodzą, że nieprawidłowości związane z rozwojem motorycznym u dzieci są obecne również w ich dorosłym życiu (Alvarez i in. 2019). Dlatego wiek przedszkolny jest bardzo istotny dla harmonijnego rozwoju, bazującego na prawidłowych wzorcach ruchowych, które stanowią podstawę dla nabywania bardziej skomplikowanych umiejętności. W pierwszych latach życia dziecka rozwój motoryczny determinuje rozwój poznawczy, ponieważ poprzez nabywanie poszczególnych umiejętności ruchowych dziecko poznaje świat. Ponadto dzięki postępom motorycznym dziecko nabywa doświadczeń sensorycznych, które kształtują procesy przetwarzania bodźców oraz odpowiedniej reakcji na bodziec. Noworodek wyposażony jest w zestaw odruchów pierwotnych, które dają możliwość zautomatyzowanej odpowiedzi na bodźce zewnętrzne (Cieszyńska, Korendo 2007). Z czasem, wraz z dojrzewaniem centralnego układu nerwowego, odruchy pierwotne zanikają i pojawia się celowość wykonywanych ruchów. Dziecko zaczyna wykorzystywać swoje ciało do poznawania świata.

Ważną rolę w tym procesie odgrywa mała motoryka, ponieważ dzięki dłoniom dziecko może dotykać i trzymać przedmioty, z czasem nimi manipulować, gromadząc 
informacje na temat otaczającej rzeczywistości. Jak podają Jagoda Cieszyńska i Marta Korendo, „stały wzrost sprawności w tym zakresie pozwala mu na zdobywanie wrażeń czuciowych i wzrokowych, a w późniejszym wieku na sprawne wykorzystanie ręki jako cennego i głównego narzędzia” (Cieszyńska, Korendo 2007: 36). Droga do uzyskania wysokiej specjalizacji ręki jest długa i skomplikowana. Przebiega etapowo według trzech praw rozwojowych: prawa cefalokaudalnego, proksymalno-dystalnego oraz łokciowo-promieniowego. Prawo cefalokaudalne zakłada stopniowe osiaganie kontroli ruchowej, która rozwija się od głowy do kończyn dolnych (Piotrowska-Madej, Żychowicz 2017). Stąd też w pierwszych miesiącach życia dziecko uczy się unoszenia głowy, leżąc na plecach oraz na brzuchu, później opierając się na przedramionach, oraz zmiany jej pozycji szczególnie w reakcji na bodziec. W kolejnych miesiącach nabywa stabilizację centralną, która umożliwia pionizację; dziecko uczy się siedzieć, później stać oraz zyskuje umiejętności lokomocyjne. Prawo proksymalno-dystalne mówi o stopniowym pozyskiwaniu stabilizacji tułowia od centrum w kierunku kończyn (Piotrowska-Madej, Żychowicz 2017: 31).

Liczna grupa dzieci w wieku przedszkolnym i wczesnoszkolnym z problemami w obrębie kończyny górnej prezentuje obniżone napięcie mięśniowe mięśni posturalnych. Rozkład i wielkość napięcia mięśniowego decyduje o właściwym rozwoju wzorców ruchowych, a patologie mogą prowadzić do wykształcenia mechanizmów kompensacyjnych. „Prawidłowa jakość wzorców ruchowych przy prawidłowej dystrybucji napięcia posturalnego zapewnia centralną stabilizację i obwodową mobilność ruchów (Piotrowska-Madej, Żychowicz 2017: 33). Właściwa wielkość i rozkład napięcia mięśniowego umożliwiają prawidłowy rozwój dużej i małej motoryki. Prawo łokciowo-promieniowe uwzględnia rozwój chwytania od piątego palca dłoni do kciuka (Piotrowska-Madej, Żychowicz 2017: 33). Ponadto w procesie specjalizacji ręki bardzo istotne są reakcje równoważne, które stanowią zautomatyzowaną odpowiedź ciała na zmiany jego położenia oraz wpływają na ogólną sprawność ruchową.

Od momentu przyjścia na świat dziecko rozwija umiejętności chwytania i manipulowania przedmiotami, które poznaje za pomocą zmysłów dotyku oraz wzroku. Chwytanie początkowo jest czynnością odruchową, jednak około czwartego miesiąca życia staje się czynnością celową i dowolną. Wraz czynnością chwytania dziecko doskonali umiejętność manipulowania. W kolejnych miesiącach uczy się wyciągać ręce po zabawkę oraz przekładać ją z ręki do ręki. Początkowo w manipulowaniu przedmiotami uczestniczy cała kończyna górna. Z czasem dziecko zdobywa kontrolę dystalną placów oraz rozwija chwyt pęsetowy. $\mathrm{Na}$ tym etapie jest w stanie przekładać, przesuwać, obracać przedmiot w dłoniach i palcach. Świadczy to o poziomie zręczności dziecka i gotowości wykonywania trudnych ruchów precyzyjnych, które są potrzebne podczas wykonywania wielu czynności tj. rysowanie, cięcie, zapinanie guzików itp. Dojrzałość chwytu jest zdeterminowana 
dojrzałością centralnego układu nerwowego, kontrolą posturalną, planowaniem ruchowym, koordynacją wzrokowo-ruchową oraz integracją sensoryczną, a jej stopień ocenia się poprzez uzyskanie funkcji stabilizacyjnej i manipulacyjnej, umiejętności dostosowania siły i kontroli trzymanego przedmiotu oraz wykształcanie łuków dłoni (Cieszyńska, Korendo 2007: 31).

Umiejętności chwytne dziecka specjalizują się w pierwszym roku życia, a ruchy ręki stają się coraz bardziej płynne, dokładne, kontrolowane. W drugim roku życia dziecka pojawia się tzw. manipulacja specyficzna, czyli zdolność do używania przedmiotów zgodnie z ich przeznaczeniem, a wielokrotne powtarzanie danej czynności daje dziecku większą precyzję ruchów i doskonalenie danej umiejętności (Cieszyńska, Korendo 2007: 47). W tym czasie można dostrzec kształtującą się lateralizację. Dziecko wybierając przedmiot do manipulowania, często posługuje się ręką dominującą, co ostatecznie zostaje zweryfikowane między trzecim a czwartym rokiem życia. W drugim roku życia rozwijają się również zdolności manualne, dziecko sięga po kredki i pisaki, eksplorując możliwości owych narzędzi, buduje wieżę z klocków, odkręca zakrętki. Doskonali się wówczas koordynacja wzrokowo-ruchowa, która jest sprzężona z rozwojem manualnym. Dziecko najczęściej posługuje się jednym z prymitywnych chwytów pisarskich, które angażują całą kończynę górną. W trzecim roku życia dziecko usprawnia ruchy precyzyjne, wykonując takie czynności jak rozpinanie guzików czy wkładanie żetonów do skarbonki. Podczas czynności grafomotorycznych wykonuje dynamiczne ruchy, angażując przy tym obręcz barkową oraz staw łokciowy, dopiero na późniejszym etapie odblokowuje nadgarstek. W czwartym roku życia dziecko stabilizuje staw barkowy oraz układa przedramię na stole. Umożliwia to uruchomienie nadgarstka. Jednak palce ustawione są na narzędziu pisarskim nieruchomo. Mówi się wtedy o przejściowych chwytach pisarskich (Piotrowska-Madej, Żychowicz 2017: 101). U dzieci w wieku przedszkolnym pojawiają się chwyty dojrzałe, efektywne, które występują również u dorosłych. Dają one największą precyzję i ergonomię. Można zatem stwierdzić, że przygotowanie motoryczne do wyspecjalizowania czynności precyzyjnych wymaga właściwie funkcjonujących mięśni posturalnych, stabilizacji kończyny górnej poprzez odpowiednią pracę obręczy barkowej, mobilności palców oraz nadgarstka. Ważne są również kontrola ruchów oraz siła i wytrzymałość mięśniowa, która wpływa na jakość motoryczną.

\section{Terapia ręki w założeniach metody Marii Montessori}

Trudności dzieci przedszkolnych i wczesnoszkolnych związane z osiągnięciem dojrzałości motorycznej najczęściej mają swoje źródło w niewłaściwym rozłożeniu napięcia mięśniowego, nieprawidłowej postawie ciała, również podczas siedzenia, braku 
kontroli ruchów, problemach z koordynacją bilateralną oraz nieustaloną lateralizacją. Takie dzieci cechuje niezborność ruchowa, mają kłopoty z czynnościami samoobsługowymi, przejawiają niechęć do wykonywania prac plastycznych oraz czynności manualnych tj. cięcie nożyczkami, klejenie, lepienie z plasteliny, posługują się nieprawidłowym chwytem przyrządu pisarskiego.

W odpowiedzi na owe trudności powstała terapia ręki, która zakłada usprawnianie małej motoryki, czyli precyzyjnych ruchów dłoni i placów przy jednoczesnym zaangażowaniu całej kończyny górnej, w celu poprawy jakości jej funkcjonowania i doskonalenia ruchów precyzyjnych. Terapia ręki jest skierowana do dzieci, które przejawiają: zaburzenia napięcia mięśniowego mięśni posturalnych oraz w obrębie kończyny górnej, problemy z wykonywaniem codziennych czynności, w tym czynności samoobsługowych, trudności w zabawach manipulacyjnych, niechęć do zadań grafomotorycznych i innych zabaw plastycznych, prezentują zaburzenia koordynacji-wzrokowo-ruchowej, koordynacji bilateralnej oraz nieprawidłową postawę ciała. Zajęcia terapeutyczne zakładają usprawnianie pracy wielu grup mięśniowych w tym: ćwiczenia mięśni brzucha i grzbietu, ćwiczenia rozmachowe i rozruchowe, stymulujące głównie obręcz barkową, manualne, manipulacyjne doskonalące pracę stawu łokciowego, nadgarstka oraz palców. Zajęcia kończą się ćwiczeniami relaksującymi oraz masażykami. Ważne jest, aby w pracy terapeutycznej z dzieckiem wykorzystać zależności pomiędzy dużą i małą motoryką.

Dla sukcesu terapii bardzo istotne są powtarzalność i częstotliwość wykonywanych ćwiczeń, dlatego warto odnaleźć w codziennych czynnościach takie aktywności, które będą wspierały rozwój motoryczny dziecka oraz wyrównywały dysharmonie. Niejednokrotnie wystarczy dobrze przygotowane otoczenie, umożliwiające rehabilitację zaburzonych funkcji podczas wykonywania prostych czynności. Takie podejście prezentuje koncepcja pedagogiczna Marii Montessori, która pisze:

[...] jednym z głównych przedsięwzięć naszej metody było przemycanie wychowania fizycznego do życia dzieci przez wdrożenie go do codziennego praktycznego życia. Nasza metoda traktuje wychowanie ruchowe i wychowanie umysłowe dziecka jako nierozerwalną całość. [...] Ruch jest zatem podstawowym czynnikiem niezbędnym do życia i proces wychowania nie może być jego hamulcem, lecz ma być pomocny w tym, by dobrze wykorzystać energię i pozwolić dzieciom na prawidłowy rozwój. [...] Otoczenie, w którym żyje dziecko, jest salą gimnastyczną, gdzie może ono doskonalić wszystkie ruchy (Montessori 2014: 75, 77).

Wspieranie indywidualnego rozwoju dziecka poprzez otoczenie przygotowane ze względu na potrzeby dzieci daje możliwość obserwowania i analizowania wykonywanych czynności oraz opracowywania nowych materiałów doskonalących zaburzone sfery (Surma 2016). Osoba dorosła (terapeuta, nauczyciel lub rodzic) tworzy pomoce, 
zwracając uwagę na cel i praktyczne zastosowanie ćwiczonych umiejętności. Następnie towarzyszy dziecku w odkrywaniu odpowiedniego użycia różnych przedmiotów, lub powoli prezentuje przebieg sekwencji czynności, które tworzą całość i prowadzą do osiągnięcia sukcesu wykonywanego działania (Melucco 2009: 55). Dziecko ma możliwość przeanalizowania, zapamiętania oraz zautomatyzowania przebiegu czynności.

Maria Montessori zauważyła dużą potrzebę ruchu dzieci i jego wpływ na rozwój umysłowy, dlatego ruch towarzyszy większości aktywności przez nią zaproponowanych. Dzieci w salach montessoriańskich mają możliwość swobodnego przemieszczania się, eksplorując przestrzeń oraz wybierając sobie miejsce do pracy (Hellbrügge 2009: 19). Montessori dostrzegła, że szczególnie małe dzieci uwielbiają przebywać na podłodze, dlatego umożliwiła im wykonywanie różnych aktywności na małych, prostokątnych dywanikach, które pełnią funkcję stolika. Praca dziecka na podłodze daje możliwość obserwowania pozycji ciała, jakie przyjmuje podczas siedzenia, i wyciagnięcia wniosków na tej podstawie. Dzieci z obniżonym napięciem mięśniowym centrum częściej siadają układając nogi w pozycji „W”. Ponadto przenoszenie dywanika i jego rozwijanie oraz zwijanie aktywuje pracę mięśni posturalnych, stymuluje propriocepcję oraz praksję, angażuje także pracę obręczy barkowej. Wśród ćwiczeń kształtujących kontrolę i koordynację dużych ruchów Montessori wyróżniła m.in. przenoszenie krzesełka, małego stoliczka, czy chodzenie po namalowanej na podłodze elipsie. Ponadto Montessori uwzględnia zadania wykonywane w ogrodzie. Zachęca do grabienia liści, sadzenia warzyw, dbania o kwiaty. Wszystkie te ćwiczenia doskonalą pracę mięśni posturalnych, wpływają na utrzymanie równowagi, koordynację wzrokowo-ruchową, stymulują propriocepcję, normalizują pracę kończyny górnej. Dodatkowo aktywności te wykonywane w skupieniu doskonalą koncentrację uwagi. „Ćwiczenie równowagi i ćwiczenie analizy wpływają na doskonalenie wykonywania danej czynności. Doskonalą mechanizmy równowagi i przyzwyczajają dziecko do tego, by z uwagą śledziło każdy ruch" (Hellbrügge 2009: 86).

Montessori wyróżniła również ćwiczenia doskonalące małą motorykę, które stanowią przygotowanie do czynności bardziej precyzyjnych. Wśród nich wymieniła m.in. przesypywanie ziaren za pomocą łyżki oraz z dzbanuszka do dzbanuszka, przelewanie płynów do jednego lub większej liczby naczynek. Zadania te doskonalą koordynację wzrokowo-ruchową, ćwiczą mięśnie palców, chwyt precyzyjny oraz normalizują pracę obręczy barkowej. Wraz ze wzrostem umiejętności dzieci aktywności te można modyfikować, proponując przesypywanie drobniejszych ziaren, posługiwanie się szczypcami, pęsetą lub innymi przyrządami, przelewanie z użyciem lejka, pipety itp. (Surma 2016).

Maria Montessori wyróżniła również szereg ćwiczeń dotyczących troski o własną osobę. Należą do nich m.in. ramki samoobsługowe z różnego rodzaju zapięciami, które doskonalą precyzyjne ruchy placów, dostosowanie siły do wykonywanego zadania, koordynację wzrokowo-ruchową oraz koordynację bilateralną, normalizują 
pracę całej kończyny górnej oraz kształtują praksję. Ramki samoobsługowe pełnią funkcję trenażera i przygotowują do wykonywania trudnych sekwencji ruchowych w codzienności. Ponadto Montessori zwróciła uwagę na, wydawałoby się, trywialną czynność, jaką jest mycie rąk, i ujęła ją w kategorię ćwiczenia. Powtarzanie schematu tej czynności ma duże znaczenie terapeutyczne. Dziecko nie tylko uczy się określonej sekwencji ruchów, ale reguluje napięcie mięśniowe poprzez kontakt z mydłem (stymulując dodatkowo zmysł węchu), kształtuje również ruchy asocjacyjne palców oraz rozluźnia nadgarstek.

Kolejna grupa ćwiczeń dotyczy troski o otoczenie. Wykonując codzienne czynności, dziecko uczy się dbać o swoje otoczenie jednocześnie stymulując dużą i małą motoryką. W tej grupie ćwiczeń wyróżniamy między innymi mycie stołu, które doskonale wpływa na obręcz barkową. Kreśląc duże ruchy kończyną górną, dziecko wykonuje ćwiczenia rozruchowe. Ponadto czynność ta wpływa na siłę i rozkład napięcia mięśniowego kończyny górnej, kiedy dziecko moczy i wyciska szmatkę. Doświadcza również zależności między włożoną siłą w wyciskanie szmatki a jej poziomem wilgotności - uczy się dostosowywać siłę do zadania. Inną czynnością wyróżnioną w tej grupie jest zamiatanie. Czynność ta doskonali ruchy kończyny górnej. Ćwiczenie to można modyfikować i urozmaicać, proponując dziecku posługiwanie się różnego rodzaju zmiotkami (z rączką lub bez) lub malutkimi przyborami do zamiatania, podczas użycia których dziecko utrwala posługiwanie się chwytem pęsetowym.

W salach montessoriańskich znajduje się wiele zestawów do ćwiczeń praktycznego życia, które doskonale stymulują rozwój motoryczny dzieci. Ćwiczenia angażujące ruchy obręczy barkowej to m.in. zaplatanie warkocza, mielenie kawy za pomocą ręcznego młynka, pranie szmatek na tarce oraz rozwieszanie ich na wieszaku, rysowanie kredą na dużej tablicy, tarcie mydła, czyszczenie butów, rozcieranie kredy w moździerzu, malowanie na sztaludze, polerowanie metalu, przesiewanie itp. Ćwiczenia doskonalące precyzyjne ruchy palców oraz siłę mięśniową to m.in. otwieranie i zamykanie różnego rodzaju pudełeczek, odkręcanie i zakręcanie buteleczek, wyszywanie, nawlekanie korali, zakręcanie i odkręcanie śrubek, zamykanie i otwieranie kłódek za pomocą klucza, zapinanie i odpinanie klamerek, wyrabianie ciasta, wrzucanie monet do skarbonki itp. Praca z materiałem Montessori uczy dzieci nie tylko wykonywania określonych czynności, ale również dokładności, z jaką mają zostać wykonane. Montessori pisze: „Generalnie ruch jest prostą pracą, lecz jeśli zaszczepi się w niego element perfekcji, jego wartość, znaczenie wzrośnie” (Montessori 2014: 80). Dlatego oprócz zachęcania dzieci do wielokrotnego wykonywania zadań, nauczyciel powinien powtarzać przebieg danej czynności powoli i dokładnie, tak by dziecko mogło odwzorować jego działanie. Dziecko poddaje nieświadomej analizie każdy ruch, nabywając umiejętność ich automatyzowania, czyli praksji. 
Maria Montessori opracowując materiały rozwojowe, wykorzystała zasadę izolacji trudności. Mówi ona o tym, że określony materiał ma głównie doskonalić jedną, określoną sprawność. Mimo to warto zdać sobie sprawę, że samo przenoszenie przedmiotów z półki na miejsce pracy jest ćwiczeniem równowagi, koordynacji oraz propriocepcji. Dlatego tak istotne jest, aby dzieci miały możliwość samodzielnego sięgania po zestawy ćwiczeń i przenoszenia ich w odpowiednie miejsce. Prezentując swoje pomoce, Montessori zwracała uwagę na sposób ich przenoszenia, np. czerwone sztangi, materiał sensoryczny, którego głównym celem jest dostrzeganie zmiany długości poszczególnych elementów, powinien być przenoszony tak, aby ręce dziecka obejmowały końce sztang. W takim ułożeniu ciała dziecko pracuje nad postawą oraz mocno angażuje obręcz barkową, zwiększa zakres ruchu. Przenoszenie różowej wieży, materiału kształtującego umiejętność różnicowania wielkości, prowadzi do utrwalenia chwytu pęsetowego oraz stymulacji propriocepcji. Praca z czterema blokami cylindrów, oprócz sensorycznej stymulacji, daje możliwość posługiwania się chwytem pęsetowym. Zabawy z szorstkimi tabliczkami sprawiają, że dziecko rozluźnia nadgarstek i tzw. lekką ręką przesuwa po ich płaszczyźnie, by wyczuć różnice gradacji. Poznawanie kształtu podstawowych figur geometrycznych w komodzie geometrycznej odbywa się poprzez wodzenie palcami po brzegach figur. W ten sposób dziecko przygotowuje się do kreślenia po śladzie oraz mieszczenia się w konturze. „Kiedy w ćwiczeniach kształtujących zmysły dzieci ruszały rękami w różnych kierunkach i ściśle określonym celu, jednostajnie powtarzając te same gesty, nieświadomie przygotowywały się do pisania" (Montessori 2014: 178). Wszystkie materiały rozwojowe Montessori są wykonane z drewna, zatem ich waga sprzyja stymulowaniu propriocepcji.

Zarówno w terapii ręki, jak i metodzie Montessori dąży się do osiągnięcia umiejętności swobodnego pisania jako czynności wyższego rządu, wymagającej skomplikowanej i precyzyjnej pracy całej kończyny górnej oraz odpowiedniej pozycji ciała podczas siedzenia. Maria Montessori opracowała materiały, które pośrednio przygotowują dziecko do wyspecjalizowania ręki. Zadbała zarówno o ćwiczenia dużej, jak i małej motoryki. Montessori stworzyła również pomoce, które bezpośrednio wpływają na umiejętności grafomotoryczne. Są to metalowe figury, dzięki którym dziecko ćwiczy odrysowywanie i obrysowywanie figury oraz jej wypełnienie, trzymając się w konturze. Pracując z tym materiałem, posługuje się kolorowymi kredkami, ćwicząc właściwy chwyt pisarski, tonus mięśniowy oraz kierunek wykonywania zadania. Montessori opracowała również materiał, który bezpośrednio wpływa na kształtowanie umiejętności zapisywania liter, czyli szorstki alfabet. Dzięki tej pomocy dzieci uczą się kształtu liter, wodząc po szorstkiej fakturze, uruchamiając tym samym pamięć mięśniową. Ręka dzieci jest swobodna, a w dotykanie litery zaangażowane są głównie dwa palce: wskazujący i środkowy. Dzięki temu dziecko uczy się ruchów asocjacyjnych palców, pracuje nad napięciem mięśniowym oraz koordynacją wzrokową ruchową. 


\section{Zadania terapeutów}

Problemy motoryczne są coraz częstszym zjawiskiem w szkołach oraz przedszkolach. Dzieci prezentują zaburzenia rozwoju motoryki dużej oraz małej, są niechętne do wykonywania zadań związanych zarówno z małym, jak i dużym ruchem. Zadaniem pedagogów oraz terapeutów jest stworzenie dobrych warunków do realizowania żmudnych ćwiczeń oraz ich powtarzania i utrwalania nabytych umiejętności. Kluczem do osiągnięcia sukcesu jest właściwe zmotywowanie dziecka do wykonywania konkretnych zadań stymulujących rozwój motoryczny. Doświadczenie pedagogów montessoriańskich pokazuje, że materiał rozwojowy stworzony przez Marię Montessori oraz jego kontynuacja stanowią dla dzieci atrakcyjne pomoce terapeutyczne, z którymi chętnie pracują bez poczucia wykonywania trudnych i mozolnych ćwiczeń. Warto również pamiętać o szeregu innych aktywności, które, w atrakcyjny dla dziecka sposób, doskonalą jego rozwój poznawczy. Są to m.in. zajęcia ceramiczne, sensoplastyczne, majsterkowanie, szycie, szydełkowanie i inne. Ważne jest, aby nauczyciele i specjaliści byli świadomi możliwości terapeutycznych, jakie daje wykonywanie prostych, codziennych czynności. Stworzenie odpowiednich warunków, w których dzieci będą mogły wielokrotnie ćwiczyć konkretne czynności umożliwi wyrównywanie dysharmonii oraz pozytywnie wpłynie na ich rozwój fizyczny i psychiczny.

\section{Bibliografia}

Alvarez V., Gonzalez L. S., Nelson L. E. (2019). Do Gross and Fine Motor Skills Differentially Contribute to Language Outcomes? A Systematic Review, „Frontiers in Psychology”, https://doi.org/10.3389/fpsyg.2019.02670 [dostęp: 20.09.2021].

Cieszyńska J., Korendo M. (2007). Wczesna interwencja terapentyczna. Stymulacja rozwoju dziecka od noworodka do 6 roku życia, Kraków: Wydawnictwo Edukacyjne.

Hellbrügge T. (2009). Zasady pedagogiki Montessori jako pomoc terapentyczna. Zalety pedagogiki montessorańskiej w placówkach integracyjnych, [w:] Dziecko i dorosty w koncepcji pedagogicznej Marii Montessori - teoria i praktyka, red. B. Surma, Łódź-Kraków: Wydawnictwo Palatum.

Melucco P. Życie praktyczne: „wczorajsza” innowacja dziś okazja sprawdzania się w relacjach ze środowiskiem i innymi osobami, [w:] Pedagogika Marii Montessori w Polsce i na świecie, red. B. Surma, Łodź-Kraków: Wydawnictwo Palatum.

Montessori M. (2014). Odkrycie dziecka, Łódź: Wydawnictwo Palatum.

Piotrowska-Madej K., Żychowicz A. (2017). Smart Hand Model. Diagnoza i terapia ręki u dzieci, wyd. 1, Gdańsk: Wydawnictwo Harmonia.

Surma B. (2016). Edukacja jezykowa w koncepcji pedagogicznej Marii Montessori, „Edukacja Elementarna w Teorii i Praktyce”, (23/1), s. 62-76. https://czasopisma.ignatianum.edu.pl/eetp/article/view/373/632 [dostęp: 3.09.2021]. 
Surma B. (2016). Innowacyjne rozwiazania w metodzie Marii Montessori, „Edukacja Elementarna w Teorii i Praktyce, 1 (22/4), s. 9-24. https://czasopisma.ignatianum.edu. pl/eetp/article/view/492/657 [dostęp 3.09.2021].

\section{ADRES DO KORESPONDENCJI}

Magda Utrata

Akademia Ignatianum w Krakowie e-mail: magda.utrata@ignatianum.edu.pl 